\title{
The Year's Work in Cataloging, 1999
}

Amy K. Weiss and Timothy V. Carstens

The challenge of cataloging Web sites and electronic resources was the most important issue facing the cataloging world in the last year. This article reviews attempts to analyze and revise the cataloging code in view of the new electronic environment. The difficulties of applying traditional library cataloging standards to Web resources has led some to favor metadata as the best means of providing access to these materials. The appropriate education and training for library cataloging personnel remains crucial during this transitional period. Articles on user understanding of Library of Congress subject headings and on cataloging practice are also reviewed.

$\mathrm{T}$ his review of the literature on cataloging for 1999 reveals a discipline in transition. The "Year's Work in Cataloging" articles that have appeared in earlier issues of Library Resources \& Technical Services have been overviews of a relatively confined universe of print materials. Like them, this article surveys the many significant contributions to cataloging that have recently appeared in the print literature. It also, however, examines working documents publicly available on the Web that were created by the Association for Library Collections \& Technical Services Committee on Cataloging: Description and Access (CC:DA), the Joint Steering Committee for the Revision of AACR (JSC), and by other bodies responsible for the creation of cataloging rules. The JSC is now in the process of making the most important revision to the cataloging code since the adoption of AACR2 in 1981. Without an examination of these materials it is not possible to fully grasp the scope of the major changes on the horizon in cataloging.

The Internet, still a novelty in 1993 when the last "Year's Work in Cataloging" articles were published, has become the single most important phenomenon in contemporary librarianship. The pressure and problems of integrating Web materials into the library have changed the environment in libraries enormously, and the full impact and implications of the Web cannot at this juncture be accounted. The mercurial, infinitely flexible Web forces us to examine in depth all aspects of current cataloging, from the difference between monographs and serials, to the relationship of monographic materials to one another, to the continued viability of the Machine Readable Cataloging (MARC) communications format, to the underpinnings of the Anglo-American Cataloging Rules themselves.

\section{Theory} State University, Boone, North Carolina, and Timothy V. Carstens (carstens@ wcuvaxl.wcu.edu) is Head of Cataloging and Acquisitions, Western Carolina University, Cullowhee, North Carolina.

Manuscript received June 2, 2000; accepted for publication August 5, 2000. 
rules using conceptual modeling. He analyzes a variety of cataloging rules, chiefly from AACR2, 1988 revision, chapter 1 , in terms of whether the rules promote or "orient" toward cost-effectiveness, identity, contents, or consistency. Delsey's work, "The Logical Structure of the AngloAmerican Cataloging Rules," is probably the most influential and comprehensive examination of the structure of the cataloging rules. Delsey stated, "the methodology used in this study is derived from techniques used in system development projects . . . entity-relationship and object-oriented models [which] are used as the basis for identifying the key entities or objects about which an organization needs to keep data and clarifying the data-related business rules that apply within the organization prior to designing the layout of databases to support the organizations' business activities" (Delsey 1998, 1). Šauperl and Saye analyzed previous research on the possibility of creating expert systems for descriptive cataloging and summarize the obstacles to the creation of such a system. They concluded that inconsistencies in the language and structure of the code are major difficulties for the creation of expert systems, but consider that cataloger experience and the ability to interpret rules are also significant (Šauperl and Saye 1999).

Relationships in the catalog were the focus of Leazer and Smiraglia's work on the complexity of bibliographic relationships. They found that many works are part of bibliographic families and have a system of relationships that are not well explored in the library catalog, since uniform titles and uniform name headings do not express all aspects of interrelation (Leazer and Smiraglia 1999). Works that are canonical (or popular) have a particularly complex set of relationships (Smiraglia and Leazer 1999).

Seymour Lubetzky remains a powerful influence on those studying the form of the catalog and the form of cataloging rules. Leazer mentioned him as an influence (St. Lifer 1999). Taniguchi also references him. His paper on "form headings" (currently either uniform titles or corporate headings), written for an ALA committee in the mid-1950s, is noteworthy since it deals with the problem of modifying standards to meet a presumed difference in circumstance. Lubetzky's analytical approach remains relevant, and his references to the earliest history of cataloging serve to remind us how much things stay the same even though the technology of the catalog has changed.

While not published in 1999, the pivotal recent works on the nature of the code continue to be the papers presented at the International Conference on the Principles and Future Development of AACR held in Toronto in 1997. The conference proceedings, published in 1998, include important works by Hirons and Graham, Yee, Howarth, and Delsey. These papers have become the philosophical underpinning for much of the work currently being done on the cataloging codes.

\section{Revising AACR}

A number of critical problems with the code, as it is currently written, were illuminated at the conference. Two critical problems, in the terminology of the CC:DA, are known as the multiple characteristics problem and the format variation problem (ALCTS CC:DA 1999, 1). The multiple characteristics problem results from the fact that, in addition to physical format, every document potentially also has the following aspects: type of publication, published vs. unpublished, fundamental content, and method of management and reproduction. AACR2 rule 0.24 appears to give primacy to the "physical carrier" aspect. In other words, a videocassette is cataloged using chapter 7 of the rules because it is a recording of visual images on magnetic tape. Delsey (1998) has demonstrated that AACR2 is inconsistent about the physical carrier principle. For example, cartographic information-whether on paper, transparencies, or threedimensional models - is cataloged using chapter 3 because of the cartographic content of the items. In this case, the content of the item, not the carrier, determines its category. In addition, AACR2 makes the unwarranted assumption that each physical carrier is restricted to only one of the class of materials chapters in AACR2 (ALCTS CC:DA Task Force on Rule 0.24 [ALCTS CC:DA TF 0.24] 1999). This means that a relevant rule cannot be applied when it is not part of the class of material chapter being used to catalog the document. Confusion is also caused by the fact that many different types of content can often be put on the same carrier. For example, maps, music, and text can all be digital. In some cases, the scope notes in AACR2 chapters appear to exclude altogether certain categories of materials from treatment by AACR2 (ALCTS CC:DA TF 0.24 2000).

The format variation (or multiple versions) problem relates to another function of rule 0.24 . Rule 0.24 is the only place in AACR2 that addresses the question of whether to create a new record if a record for a similar item already exits in the catalog. As it is now written, the rule implies that a new record should be created whenever there is any variation in "physical carrier" between two documents, even if the documents contain the same intellectual or artistic content (ALCTS CC:DA TF 0.24 1999). For example, under the current rules, separate records are created for the film and video versions of a feature motion picture. Separate records are also created for the print, microfilm, and online versions of a periodical, even if all three versions contain exactly the same content. The growth in the number and variety of electronic resources has made this problem more acute since electronic resources are capable of carrying so many different types of content. As a result of the format variation problem, the catalog user may have to wade through many catalog records that represent essentially the same thing. In their local catalogs, many libraries are already adding holdings for various 
versions of serials to only one catalog record. Even though this local practice has been sanctioned by the Cooperative Online Serials Program (CONSER), it is still contrary to AACR2 rules.

Another problem that has become especially acute with the advent of electronic resources resides in AACR2's concept of seriality. Because they do not have a predetermined conclusion, Web sites and databases exhibit many of the attributes of serials. Yet these resources are not issued in successive parts and do not bear numeric or chronological designations, which are the other AACR2 attributes of seriality. Since these electronic resources lack the other "serial" attributes, they cannot be treated as serials by AACR2; yet because of their continuing nature they cannot be handled effectively as monographs. This means that there is now a large and growing category of bibliographic resources that cannot be handled effectively by the code.

A final problem with the code is that it assumes that the content of a document is permanently fixed within a physical object. Again, this is not necessarily the case with remotely accessible electronic items, which can change from one viewing to another. Although the current rules allow the cataloger to handle this material by taking a "snapshot" (Delsey 1998, 35) of the item while at the same time leaving certain variables vague, this technique is not adequate because there is no way to know when content might have changed or whether the "snapshots" compiled by various catalogers will be sufficiently similar to identify the item.

A number of different committees and organizations have been working on the above-mentioned problems with the code. The definition of seriality was tackled in a report prepared for the JSC by Hirons and others entitled "Revising AACR2 to Accommodate Seriality" (1999). Hirons began by distinguishing "finite" publications from "continuing" publications. Finite publications are complete or are intended to be complete and include traditional monographs. Continuing publications are intended to be continued for an indeterminate period and include traditional serials. They also include a conceptually new type of publication called integrating resources (though certain types of integrating resources can also be finite publications). Hirons defined integrating issuance as "a form of issuance that describes bibliographic resources that are added to or changed by means of updates that do not remain discrete and are integrated into the whole" (Hirons 1999). Integrating resources include loose-leaf publications, Web sites, and databases. Hirons also recommended refinement of the AACR2 definition of serial to make the distinction between a traditional serial and an integrating resource clearer. The JSC has endorsed the concept of integrating resources and Hirons has been commissioned by the JSC to propose specific descriptive rules to deal with them (JSC 1999). The proposed revisions are now available for review
(Hirons 2000). These new rules, if adopted, should allow AACR2 to handle more effectively this rapidly growing category of resources.

Hirons's report also recommended a series of modifications to AACR2 to deal with the fact that continuing resources change continually over time (Hirons 1999). As noted above, the current rules only allow the cataloger to consider a "snapshot" of the evolution of these resources. Hirons's solution is to require catalogers to consider the whole publication, not just a single issue or manifestation (as in the case of integrating resources). Proposed changes emphasize identification of the whole publication over merely transcribing information from the most current manifestation. Hirons recommended focusing on the description of variable information, ignoring obvious errors in titles, minor title changes, and most "other title information" when cataloging continuing resources. Hirons would require the identification of all of the item(s) used as the basis of description (or, in the case of integrating resources, all times that the resource was viewed). She would also apply to integrating resources and the use of notes indicating other titles by which a resource is known. Her report recommended that the source for the title or statement of responsibility should be the latest issue or iteration of a resource. Closely connected with this suggestion is the recommendation that a uniform title be added to successively cataloged titles in order to provide these resources with a stable title. These two recommendations would provide the user with a more holistic approach to the whole work-i.e., both earliest and latest titles-while still providing stability. JSC has now endorsed many of these changes. The use of title information from the latest piece in hand was endorsed for integrating resources but not for traditional serials (JSC 1999). Another major change recommended by Hirons and intended to emphasize the whole work is the elimination of the concept of chief source of information for continuing resources. JSC is currently exploring the possibility of making the entire resource the chief source of information for all types of materials, not just for continuing resources (JSC 1999).

CC:DA has recommended a two-pronged solution to the multiple version problem.

It suggested that AACR2 should be reorganized by International Standard Bibliographic Description (ISBD) area so that all rules related to title, edition, etc., appear together (ALCTS CC:DA 1999, 4). The new arrangement would allow the cataloger to use every rule relevant to the resource being cataloged and does not restrict the cataloger to the rules in only one class of material chapter. It also recommended that rule 0.24 be rewritten so that all aspects of a document are brought out and so that physical carrier is no longer given primacy. The key first sentence of the proposed rule revision reads, "It is important to bring out all aspects 
of the item being described, including its content, its carrier, its type of publication, its relationship to other expressions of the same work, and whether it is published or unpublished . . . all relevant aspects should be described with no one relevant aspect taking precedence over any other" (ALCTS CC:DA 1999, 5). JSC has endorsed a staged approach to the implementation of these revisions with some changes to rule 0.24 being made immediately and further changes made should AACR2 be reorganized by ISBD area (JSC 1999). JSC is currently developing a prototype to test the feasibility of reorganizing AACR2 by ISBD area. JSC's eventual disposition of the ISBD reorganization proposal is highly uncertain at this time.

CC:DA has also made recommendations related to the format variation problem. According to CC:DA, this problem results from confusion about the purpose of bibliographic records. Should bibliographic records represent a particular expression of a work, or should they represent a manifestation of a work? Expression is "the intellectual or artistic realization of a work in the form of alpha-numeric, musical, or choreographic notation, sound, image, object, movement, etc. or any combination of the above forms." Expression excludes "aspects of physical form ... that are not integral to the intellectual or artistic realization of the work as such" (ALCTS CC:DA TF 0.24 1999). Manifestation, on the other hand, is "the physical embodiment of an expression of a work." A manifestation represents all the physical objects that bear the same characteristics, in respect to both intellectual content and physical form. When the production involves changes in physical form, the resulting product is considered a new manifestation. Changes in physical form include changes affecting display characteristics . . . changes in physical medium . . . changes in container" (ALCTS CC:DA TF 0.24 1999). Currently, new records are created whenever there is a new manifestation of a work. CC:DA has suggested that the rules be changed so that new records are created only if the expression changes (ALCTS CC:DA 1999). JSC has reserved judgment on this recommendation (JSC 1999).

Related to the format variation problem is the question of whether minor variations in a resource require a new catalog record. Although various entities (including OCLC and the LCRIs) have addressed this issue, AACR2 remains silent. JSC has endorsed this idea and has asked CC:DA to draft an appendix to AACR2 defining what constitutes major and minor changes (JSC 1999). Major changes would require the creation of a new record; minor changes would not. JSC has also asked the Library Association/British Library to prepare a draft introduction to AACR2 that would discuss the major/minor changes issue as well as other general issues related to the entire code (JSC 1999).

Since so many of the changes to the code discussed above were stimulated by the increasing importance of elec- tronic resources, it is not surprising that the section of the code that deals with these resources has also been undergoing a major revision. The process began at the international level when the International Federation of Library Associations and Institutions (IFLA) published a major revision of the International Standard Bibliographic Description for Electronic Resources [ISBD (ER), formerly ISBD $(\mathrm{CF})$ ]. CC:DA was charged with "harmonizing" AACR2 chapter 9 with ISBD (ER). The CC:DA Task Force on Harmonization of ISBD (ER) and AACR2 has now produced a final report, including recommendations for specific changes to the code (ALCTS CC:DA Task Force on Harmonization of ISBD (ER) with AACR2, 1999). These recommendations parallel many of the ones made by those committees dealing with rule 0.24 and seriality and, indeed, the chapter 9 recommendations influenced and were influenced by the other activities that have been under discussion.

The replacement of the term "computer file" with the term "electronic resource" throughout chapter 9 is the first change recommended by the CC:DA Task Force on Harmonization. Also recommended were changes to the definition of the edition of an electronic resource. Like the CC:DA report on 0.24 , the chapter 9 task force urged that a resource be considered a new edition only if there are significant changes in the intellectual or artistic content. Statements such as new release, version, level, or update, as well as changes in physical carrier, display format, or printer-related file formats would require a new record only if there were also a change in content. Like Hirons, the task force recommended that the chief source of information for an electronic resource be the entire resource, not the title screen. Other task force recommendations were concerned mainly with broadening the rules so as to make them more applicable to the large variety of electronic resources that now exist. These recommendations included broadening the scope of the rules to include new types of electronic resources; creating more specific terms for use in the file characteristics area; and the inclusion of many more current examples, particularly those related to remote resources, in the note fields.

\section{Summary of Proposed Changes}

The task forces and committees working on revision of AACR2 have proposed numerous fundamental changes to the cataloging code. Among the historic changes suggested have been the defining of the new type of resource, the integrating resource, and the creation of a new set of rules to handle this type of resource. Another proposal was to create new records only when there is a new "expression" of a work and not for every "manifestation." A new appendix and 
introduction to AACR2, as well as its reorganization by ISBD area, are possible changes that would radically alter its appearance in addition to changing its content. Finally, the many proposed changes to chapter 9 and to other parts of AACR2 to accommodate the slippery new forms of electronic resources would contribute to substantial reworking of the code. Taken together, these rule revision efforts represent some of the most important work being done in cataloging today. Catalogers are urged to follow the progress of this revision process via the Web sites listed in the bibliography of this article.

\section{Metadata}

While the JSC and others work on revision of the cataloging code and MARC to accommodate electronic resources, others have tried new approaches to bibliographic control. These new approaches revolve around the nebulous concept of metadata. Metadata is commonly defined as data about data. Aside from that rather glib definition, which is usually followed by the observation that even catalog cards are metadata, it has been rather difficult for noninitiates to discover what the furor over metadata is about and why metadata is important in information retrieval. Fietzer noted that an ALCTS subcommittee has found "more than twenty working definitions in the course of its deliberations, each one viable for the community that created it" (Fietzer 1999, 13). The confusion over how to define metadata has been well analyzed by Hopkins, who stated, "Metadata is . . . information about, primarily, electronic resources, with that information being encoded according to some scheme which is often electronic" (Hopkins 1999, 56). Compounding the confusion is the large number of metadata standards. A number of articles attempt to explain metadata. Ahronheim (1998) has written one of the most comprehensive articles, and is a good place for the novice to start reading. It describes the markup languages used and a number of the most important standards and initiatives. Summers provided links to current metadata projects and gives instructions for viewing the metadata (Summers 1999).

The Dublin Core has become the emergent standard of greatest interest to librarians because it is flexible, highly developed, and promoted by OCLC. Chepesiuk and Burk both described the genesis of the Dublin Core and describe its key elements (Chepesiuk 1999; Burk 1999).

Metadata is frequently offered as a workable alternative to full library cataloging for Web resources. Some arguments against using AACR2R and the MARC format for Web resources are noted in Chepesiuk (1999): MARC records are too difficult to make and it is not cost-effective to make MARC records for often ephemeral Web materials. Gradmann (1999) noted that the Dublin Core was intended for Web authors to make their own metadata, and one Dublin Core enthusiast quoted in Chepsiuk implied that the lack of rules for Dublin Core records makes them easy to create (Chepesiuk 1999). Gradmann made the argument that metadata is fundamentally different from cataloging, since it focuses on discovery of resources rather than description of resources, and further states that traditional description is not end user-oriented (Gradmann 1999).

For some, these arguments are reductive of the problems of description and show nothing more than an incomplete grasp of both AACR2 and the capabilities of the MARC format. Gorman discussed the difference between framework standards such as MARC or metadata, which merely name elements in the description, and content standards, such as AACR2, which specify what content is included in the catalog record (Gorman 1999). He shows the strong similarity between MARC and the Dublin Core, and warns against ignoring content standards or confusing content with framework. Gradmann as well as Milstead and Feldman are guilty of this confusion, since they emphasize controlled language in metadata as essential for increased retrieval while failing to acknowledge that metadata standards do not in any manner require controlled language (Gradmann 1999; Milstead and Feldman 1999). Milstead and Feldman admitted that the variety of metadata standards limits the usefulness of metadata for searching. They included the development of thesauri as one of the goals for unification (Milstead and Feldman 1999).

Weinberg's argument that the Web represents no more than a wrinkle on traditional problems of indexing makes a number of valuable points. She stated that the number of Web sites is not as prohibitively large as has been portrayed, noting that there were at the time of her writing approximately two million Web sites, compared to thirty-nine million records for unique materials in OCLC, and thirty million in RLIN. She also compared the structure of Web sites to periodicals, noting that even a single edition of a book can contain variants and that merely being mutable (like a loose-leaf publication) does not make Web materials unusually novel. She exhorted librarians to work on cooperative cataloging and indexing efforts, rather than spending time developing elaborate local Web pages that more often than not reference the same essential sites (Weinberg 1999).

One feature of the current environment is a large number of local or specialized initiatives. Doran's case study described the development of metadata for a large corporate Intranet, using a metadata template and controlled language terms. Her case study is notable for the fact that it emphasizes how much work was involved in the retrospective indexing of Web pages, and how difficult it was for staff, who had volunteered to assist but who had no official time set aside for performing the work, to meet deadlines (Doran 1999). Veatch emphasized how traditional library tools such 
as collection development and MARC format can be utilized in Web control. Veatch emphasized a selective approach: finding the resources that will augment the library's holdings in a given area and committing to full MARC cataloging and any associated maintenance (Veatch 1999). Porter and Bayard described a similar project undertaken at the University of Notre Dame. They emphasized cataloging sites by "reliable" producers of information and committing to using link-checking software as a database maintenance procedure. Few of their sites changed URLs or went under during the project. They noted that it took catalogers approximately thirty minutes to catalog Web sites initially and twenty minutes by the end of the project, which seems to invalidate the perception that current standards and processes are unworkable for Web materials (Porter and Bayard 1999, 391-92).

One challenge of Internet cataloging, which appears to be receiving little consideration, is that there is no definable Internet catalog. From the various forms of the book cata$\log$, through the card catalog, and even through contemporary automated systems, there is a known universe of possible searching behaviors and strategies limited by the nature of the catalog itself. The simplicity of the card cata$\log$ is the source of its nostalgic appeal. The Internet's endless sprawl can be searched by any number of tools whose search strategies can be ambiguous. Because of the diverse algorithms of various search engines it is difficult to know where to locate and how to format metadata for optimum user searching. Turner and Brackbill's (1998) research on how the use of embedded metadata (specifically the HTML META tag) affects retrieval of Web pages is significant. Pages with keyword metatags were ranked as "more relevant" to a search designed to retrieve the pages than pages without the keyword metatags. However, another type of metatag (a description metatag) exhibited no improvement in retrieval, apparently because the search engines stopped examining the document for multiple occurrences of the term after examining the description tag (Turner and Brackbill, 1998). Valauskas's examples of search engine failures in retrieving an electronic article containing imbedded metadata are also instructive. Drabenstott et al. (1999) cited Bates as stating that successful catalog searchers are those who understand the structure of the catalog rather than those who are experts on the topic that they are searching. If so, the diversity and complexity of Web search tools may continue to confound catalogers in their search for the best means of access through metadata of whatever type.

Most authors, despite their vague longing for controlled language, have focused on the descriptive aspects of metadata rather than subject retrieval. Interesting new ideas for subject access include Dovey's short article on meta-objects, which proposes intelligent documents that read and understand their own imbedded metadata and dynamically form links with other relevant documents. Ellis and Vasconcelos explored how facet analysis might be used to bridge the gap in retrieval capabilities between the word approach (used by most search engines) and true subject searches (1999). Hopefully a concrete project can be created pursuing this intriguing idea.

The MARC format was developed in 1967, making it ancient in automation terms. Hopkinson noted that the underpinnings of MARC, designed to facilitate the exchange of information on digital tape, are dated. Despite that drawback, the stability of MARC has created a near universal ability to exchange bibliographic information. "MARC use has increased since people began to prophesy its death [in 1985]" (Hopkinson 1999, 18). Metadata, with its multiple standards and formats, may not prove as resilient as MARC.

Metadata cannot currently be integrated into a standard library catalog. Instead, metadata must be attached to Web pages or it can be confined to a separate database of metadata records. This limitation leads to the issue of how many places and in how many ways it is advisable to provide access to electronic resources. It is ironic that at a time when even the largest research libraries have realized that a purchased ILS is more efficient than attempting to maintain a proprietary system, that even many small libraries feel obliged to create proprietary home pages to provide access to electronic materials. In some cases library Web pages have evolved into a shadow catalog-a nontransferable effort of the sort decried by Weinberg.

\section{Education of Catalogers and Cataloging Staff}

The realization that library standards may be useful in organizing the chaotic Internet means that the skill of catalogers may be in demand "Now that Cataloging Is Cool!" as one article trumpets (Garman 1999, 6). This excitement has not, unfortunately, translated into an interest in cataloging as an academic discipline. A study by Spillane showed that in 1998 only $52.1 \%$ of library schools required a cataloging course, compared to $77.1 \%$ in 1986 . This discouraging statistic is somewhat offset by the fact that the number of cataloging courses taught overall has risen (Spillane 1999). The removal of required cataloging courses would seem to portend that fewer prospective librarians will have exposure to cataloging and therefore not only will fewer people become catalogers, but fewer librarians overall will have a solid grasp of how to use the catalog.

Bordeianu and Seiser's article discussed educational requirements for paraprofessional catalogers in academic libraries. There is no single educational standard for paraprofessional catalogers, but most ARL libraries do not require postsecondary education for copy catalogers, 
although many accept postsecondary education in place of experience (Bordeianu and Seiser 1999). There is a general assumption of on-the-job training for professionals and paraprofessionals alike. Sill's article offered a proposed “curriculum" for on-the-job training for a professional serials cataloger (1999). Wiles-Young and Novak's article expressed concern for loss of training expertise, as professional librarians in cataloging departments become managers (1999, 450).

It is ironic that formal training in cataloging standards is considered irrelevant to the presumed creators of the new information infrastructure. In contrast, Banks convincingly showed how learning the rudiments of cataloging assists users in locating needed materials in the catalog (1999).

\section{Subject Cataloging}

The most significant research of the year was the Drabenstott study of user understanding of Library of Congress subject headings. Results of the survey, as published and analyzed in several journals, showed a uniformly low level of understanding of LCSH, with a 31\% accuracy rating for child users and a $39 \%$ accuracy rating for adult users (Drabenstott, Simcox, and Fenton 1999b). Using a similar methodology, it was shown that expert users (i.e., librarians) were more accurate at assessing the meaning of LC subject headings, but that reference and technical services librarians still scored rather low rates of $52 \%$ and $55 \%$ respectively (Drabenstott, Simcox, and Williams 1999). Drabenstott et al. argue against eliminating LCSH, but point out that the subject headings they asked the participants to analyze were extremely complex, comprising three or more concepts. It may be that fewer concepts should be worked into single headings. Another implication is that the order of headings does not seem to make much difference to any group of users. Therefore a standard order of subdivisions would save money and time in cataloging departments (Drabenstott, Simcox, and Fenton, 1999b). Certainly given the relative flexibility of contemporary OPACS, with their ability to invert headings or search keyword components, this suggestion appears sensible.

Lundgren and Simpson surveyed graduate student perceptions of the usefulness of various aspects of bibliographic description for Web materials. While they regarded subject terms as useful, the graduate students preferred summary notes or abstracts (Lundgren and Simpson 1999). One might conclude that summary notes are simply less nebulous than subject strings and do not require special knowledge to interpret.

The MARC format subject subfield was finally implemented in February 1999, but not without controversy, as reflected in the postings to AUTOCAT that followed the implementation. Hemmasi et al. give the history of subfield $\mathrm{v}$ implementation, and admit that the controversial $\mathrm{v}$ is only the first step in a larger implementation of form headings that will have to include implementation of search capabilities by the creators of integrated library systems (Hemmasi, Miller, and Lasater 1999).

Harvard University has already implemented MARC field 655 in its catalog, in response to requests from reference librarians. Beall discussed the use of form/genre headings in the Hollis catalog. The form/genre terms in the catalog are derived from multiple thesauri and include many unverified headings from copy records, activated when the field was implemented for indexing and display. The use of form/genre terms to limit searches is still largely confined to the reference users, but it appears that they do offer a useful way to improve access and search precision. Hopefully, other libraries will follow suit in adding 655 to their search indexes, which would generate impetus to create the standard thesaurus called for by Beall (1999).

\section{Practice}

While the Internet monopolized much of recent cataloging literature, other formats of material also received attention. Freeborn (1999) discussed some unusual problems in 3-D audiovisual cataloging, demonstrating another case where strict reading of AACR2 may fail to illuminate the frustrated cataloger.

The two volumes of Cataloging and Classification Quarterly devoted to cataloging of cartographic materials are an excellent addition to the complex area of map cataloging practice. Even with two volumes, the editors admitted to gaps in the coverage of topic (Andrew and Larsgaard 1999), which speaks to the need for a revision of the long out-of-print Cartographic Materials (Stibbe 1982) and some simplification in map cataloging practice.

Frohnsdorff's article is that rare bird: an entertaining article on cataloging. It explores problems with the veracity of publication information contained in erotica and bootleg recordings. Because their creators are usually operating barely within the law or outside of it, publication information on these materials is generally spurious.

With the Library of Congress's move to Pinyin romanization, issues of language transcription and display have been highlighted. Riedlmayer's article contains dramatic examples of how the failure of online catalogs to display vernacular alphabets and diacritics affects retrieval and access to materials. His examples range from the familiar (the many versions of the name Qaddafi) to the less familiar but possibly more egregious (showing how the removal of diacritics from Hungarian words reduces the language to gibberish) (Riedlmayer 1999). Automated authority control 
processes strip diacritics from headings as part of the normalization process for comparing headings. Bolick demonstrated how this can lead to erroneous name headings when applied to Chinese-language materials (1999).

There have been several articles this year on archival cataloging practice, most notably Hamburger's useful case study of three grant-funded retrospective conversion projects. Hamburger's conclusions on administration, staffing, and record quality are worthwhile reading for anyone planning a retrospective cataloging project (1999).

In summation, we stand on the threshold of a new era. The momentum is in place. In the next few years, there will undoubtedly be sweeping changes made to our cataloging rules, to our online catalogs and the records contained in them, and to the structure of subject access and analysis. The question of whether we will make things better for users is an open one. It is hoped that more research will be performed to determine how users categorize and locate information and materials and guide us in the change process.

\section{Bibliography}

Ahronheim, Judith R. 1998. Descriptive metadata: Emerging standards. Journal of Academic Librarianship 24, no. 5: 395-404. - 1999. Technical services management issues in the metadata environment. Technicalities 19, no. 6 (June-July): 4-6.

Andrew, Paige G. 1999. Cataloging the contemporary printed atlas. Cataloging \& Classification Quarterly 27, no. 1-2: 147-64.

- 1999b. A survey technique for map collection retrospective conversion projects. Cataloging \& Classification Quarterly 27, no. 3-4: 405-12.

Andrew, Paige G., and Mary Lynette Larsgaard. 1999. Maps and related bibliographic materials: Cataloging, classification, and bibliographic control. Part I, Introduction. Cataloging \& Classification Quarterly 27, no. 1-2: xvii-xx.

Anyomi, Mary E. 1999. Outsourcing cataloging functions in South Carolina public libraries. Bottom Line 12, no. 1: 29-33.

Armstrong, HelenJane, and Jimmie Lundgren. 1999. Cataloging aerial photographs and other remote-sensing materials. Cataloging \& Classification Quarterly 27, no. 1-2: 165-227.

Association for Library Collections \& Technical Services. Committee on Cataloging: Description and Access. 1999. Overview and Recommendations Concerning Revision of Rule 0.24. Accessed May 2, 2000, www.ala.org/alcts/organization/ ces/ccda/tf-024h.pdf.

Association for Library Collections \& Technical Services. Committee on Cataloging: Description and Access. Task Force on Harmonization of ISBD (ER) and AACR2. 1999. Final Report. Accessed May 3, 2000, www.ala.org/alcts/organization/ccs/ccda/tf-harm3.pdf.

Association for Library Collections and Technical Services. Committee on Cataloging: Description and Access. Task Force on Rule 0.24. 1999. Report to CC:DA 1999 Annual. Accessed May 3, 2000, www.ala.org/alcts/organization/ccs/ ccda/tf-024g.html.
Ayers, F. H. 1999. Time for a change: A new approach to cataloguing concepts. Cataloging \& Classification Quarterly 28, no. 2: 3-16.

Ayers, F. H., L. P. S. Nielsen, and M. J. Ridley. 1999. BOPAC 2: A new concept in OPAC design and bibliographic control. Cataloging \& Classification Quarterly 28, no. 2: 17-44.

Baker, Nicholson. 1999. A couple of codicils about San Francisco. American Libraries 30, no. 3 (Mar.): 35.

Banks, Julie. 1999. Teaching basic cataloging concepts to nonlibrary science students. Journal of Education for Library and Information Science 40, no. 2: 118-21.

Beall, Jeffrey. 1999. Indexing form and genre terms in a large academic library OPAC: The Harvard experience. Cataloging d Classification Quarterly 28, no. 2: 65-71.

Benaud, Claire Lise, Sever Bordeianu, and Mary Ellen Hanson. 1999. Cataloging productivity standards in academic libraries. Technical Services Quarterly 16, no. 3: 43-67.

Bolick, Hsi-Chu. 1999. Problems in the establishment of nonunique Chinese personal headings with special reference to NACO guidelines and vendor-supplied authority control. Library Resources \& Technical Services 43: 95-105.

Bordeianu, Sever, and Virginia Seiser. 1999. Paraprofessional catalogers in ARL libraries. College and Research Libraries 60, no. 6: 532-40.

Brisson, Roger. 1999. Online documentation in library technical services. Technical Services Quarterly 16, no. 3: 1-20.

. 1999b. The world discovers cataloging: A conceptual introduction to digital libraries. Journal of Internet Cataloging 1, no. 4: 3-30.

Burk, Alan. 1999. Metadata and the Dublin Core. Feliciter 45, no. 1: $60-65$.

Burnett, Kathleen, Kwong Bor Ng, and Soyeon Park. 1999. A comparison of the two traditions of metadata development. Journal of the American Society for Information Science 50, no. 13: 1209-17.

Burton, Paul F. 1999. Information professionals and the World Wide Web. Online and CD-ROM Review 23, no. 2: 103-4.

Byrum, John D. 1999. ISBD (ER): An overview. International Cataloguing and Bibliographic Control 28, no. 3 (July-Sept.): 65-66.

Carter, Christina E., Sever Bordeianu, and Nancy Dennis. 1999. The real world of integrating electronic resources into a Web OPAC. Serials Librarian 36, no. 3-4: 455-60.

Chepesiuk, Ron. 1999. Organizing the Internet: The "core" of the challenge. American Libraries 30, no. 1 (Jan.): 60-63.

Childress, Eric, Erik Jul, and Eric Miller. 1999. Un-building a mystery. Journal of Internet Cataloging 1, no. 4: 45-51.

Cole, Jim. 1999. Cataloging of digitized texts. Cataloging \& Classification Quarterly 28, no. 3: 45-54.

Condron, Lyn. 1999. New department head's staff introduction survey. Cataloging \& Classification Quarterly 28, no. 3: 95-102.

Cooknell, Jennifer. 1999. Crossing the line: The development of archival standards. Art Libraries Journal 24, no. 2: 26-30.

Cortez, Edwin M. 1999. Use of metadata vocabularies in data retrieval. Journal of the American Society for Information Science 50, no. 13: 1218-23.

Crawford, Walt. 1999. The card catalog and other digital controversies. American Libraries 30, no. 1 (Jan.): 52-58. 
Croghan, Anthony. 1999. The rules of the cataloguing game. Catalogue \& Index 132: 6-7.

Davis, Harry O., and James S. Chervinko. 1999. Map cataloging and classification: The basic who, what, and where. Cataloging \& Classification Quarterly 27, no. 1-2: 9-37.

Delsey, Tom, et al. 1998. The logical structure of the AngloAmerican Cataloguing Rules. Part I, Drafted for the Joint Steering Committee for Revision of AACR. Accessed May 2, 2000, www.nlc-bnc.ca/jsc/aacrint.pdf.

DeMeule, Marah, and Gwen Gregory. 1999. Reconcilable differences: Archivists, catalogers, and manuscript materials. Technical Services Quarterly 16, no. 4: 35-43.

DeSilva, S. M., and A. N. Zainab. 1999. Identifying and categorizing published conference proceedings. Malaysian Journal of Library and Information Science 4, no. 1 (July): 41-59.

Doran, Kelly. 1999. Metadata for a corporate intranet. Online 23, no. 1 (Jan.-Feb.): 43-50.

Dorman, David. 1999. Metadata musings. American Libraries 30, no. 1 (Jan.): 102

Dorner, Dan. 1999. Cataloging in the 21st century. Part 1, Contextual issues. Library Collections, Acquisitions, and Technical Services 23, no. 4: 393-99.

Dovey, Matthew. 1999. Meta-objects: An object-oriented approach to metadata. Ariadne 19 (Mar.). Accessed April 4, 2000, http://ariadne.ac.uk/issue19/meta-objects.

Drabenstott, Karen M., et al. 1999. Interpreting the findings of A study of library users and their understanding of subject headings. Technicalities 19, no. 4 (Apr.): 13-15.

Drabenstott, Karen M., Bonnie Roeber Dede, and Melanie Leavitt. 1999. The changes of meaning in subdivided subject headings. Cataloging \& Classification Quarterly 28, no. 3: 19-43.

Drabenstott, Karen M., Schelle Simcox, and Eileen G. Fenton. 1999. Do patrons understand Library of Congress Subject Headings? Technicalities 19, no. 1 (Jan.): 1, 7-11.

. 1999b. End user understanding of subject headings in library catalogs. Library Resources \& Technical Services 43: 140-60.

Drabenstott, Karen M., Schelle Simcox, and Marie Williams. 1999. Do librarians understand the subject headings in library catalogs? Reference and User Services Quarterly 38, no. 4: 369-87.

Dunsire, Gordon. 1999. Bringing it all back home: Retrieval and access for the global information society. International Cataloguing and Bibliographic Control 28, no. 1 (Jan.-Mar.): 13-14.

Ede, Stuart. 1999. Digital indigestion: Is there a cure? International Cataloguing and Bibliographic Control 28, no. 1 (Jan.-Mar.): 3-7.

Edwards, Jennifer, and Amanda Xu. 1999. Eeee! Serials! Providing access to online serials. Serials Librarian 36, no. 3-4: 467-73.

Ellis, David, and Ana Vasconcelos. 1999. Ranganathan and the Net: Using facet analysis to search and organize the World Wide Web. ASLIB Proceedings 51, no. 1: 3-10.

Ercegovac, Zorana. 1999. Special topic issue: Integrating multiple overlapping metadata standards. Journal of the American Society for Information Science 50, no. 13: 1165-68.

Ferrari, Roberto C. 1999. The art of classification: Alternate classification systems in art libraries. Cataloging \& Classification Quarterly 28, no. 2: 73-98.
Ficter, Darlene. 1999. Administrative and factual metadata for intranets: Issues and options. Online 23, no. 6 (Nov.-Dec.): 88-90.

Fietzer, William. 1999. Working our way through wonderland: Technical services and the sociology of metadata. Technicalities 19, no. 6 (June-July): 1, 13-15.

Fleck, Nancy W., and Margaret Rust. 1999. MicroMARC for integrated formats. Library Hi Tech 16, no. 2: 37-44.

Formson, J. W. 1999. The impact of information technology on the cataloguing process at the University of Botswana Library. African Journal of Library Archives and Information Science 9, no. 1: 17-26.

Franzmeier, Gunter. 1999. Union catalogs of serials in Germany between 1945 and 1970. Serials Librarian 35, no. 4: 111-17.

Freeborn, Robert. 1999. Cataloging of the weird. MC Journal 6, no. 2. Accessed April 3, 2000, http://wings.buffalo.edu/ publications/mcjrnl/v6n2/freeborn.html.

Frohnsdorff, Gregory. 1999. Facts? Of publication: Cataloging problems posed by deceptive information. Library Resources \& Technical Services 43: 213-22.

Garcha, Rajinder, and Lois Buttlar. 1999. Changing roles of cataloguers in British academic libraries. Library Review 48, no. 2: $66-72$.

Garman, Nancy. 1999. Now that cataloging is cool. Online 23 (Sept./Oct.), no. 5: 6.

Gilyard, Burt. 1999. Sandy Berman's last stand. City Pages 20, no. 971 (July 14): 12-21.

Gorman, Michael. 1999. Metadata or cataloguing? A false choice. Journal of Internet Cataloging 2, no. 1: 5-22.

Gradmann, Stefan. 1999. Cataloguing vs. metadata: Old wine in new bottles? International Cataloguing and Bibliographic Control 28, no. 4 (Oct.-Dec.): 88-90.

Hakala, Juha. 1999. Internet metadata and library cataloging. International Cataloguing and Bibliographic Control 28, no. 1 (Jan.-Mar.): 21-25.

Hamburger, Susan. 1999. Life with grant: Administering manuscripts cataloging grant projects. The American Archivist 62: 130-52.

Heaney, Mike. 1999. An interview with Tom Delsey. Cataloging d Classification Quarterly 28, no. 3: 3-18.

Hearn, Stephen S. 1999. Metadata structures and authority control. Technicalities 19, no. 6 (June-July): 7-9.

Hemmasi, Harriette, David Miller, and Mary Charles Lasater. 1999. Access to form data in online catalogs. ALCTS Online Newsletter 10, no. 4 (July). Accessed April 3, 2000, www.ala.org/alcts/alcts_news/v10n4/formdat2.html.

Henshaw, Robin. 1999. The First Monday metadata project. Libri 49: 125-31.

Hill, Linda L., et al. 1999. Collection metadata solutions for digital library applications. Journal of the American Society for Information Science 50, no. 13: 1169-81.

Hiller, Eileen. 1999. Scatter and save! An evaluation of the adoption of centralized classification and outsourcing. Against the Grain 11, no. 2: 18, 20-22.

Hirons, Jean, et al. 2000. Revising AACR2 to accommodate seriality, rule revision proposals submitted to the Joint Steering Committee for Revision of AACR. Accessed May 3, 2000, www.nlc-bnc.ca/jsc/ch12.pdf. 
1999. Revising AACR2 to accommodate seriality, report to the Joint Steering Committee for Revision of AACR. Accessed May 3, 2000, www.nlc-bnc.ca/jsc/ser-rep0.html.

Hirons, Jean, and Regina Reynolds. 1998. Proposal to adopt a modified model C. Accessed April 11, 2000, www.lcweb.loc.gov/ acq/conser/ModelC.html.

. 1999. Seriality: It's not just for serials any more. Library Review 48, no. 4: 163-68.

Holm, Liv Aasa. 1999. Authority control in an international context in the new environment. International Cataloguing and Bibliographic Control 28, no. 1 (Jan.-Mar.): 11-13.

Holt, Brian. 1999. Presentation of UNIMARC on the Web: New fields including the one for electronic resources. International Cataloguing and Bibliographic Control 28, no. 2 (Apr.-June): 47-48.

Hopkins, Judith. 1999. USMARC as a metadata shell. Journal of Internet Cataloging 2, no. 1: 55-68.

Hopkinson, Alan. 1999. Traditional communication formats: MARC is far from dead. International Cataloguing and Bibliographic Control 28, no. 1 (Jan.-Mar.): 17-21.

Howarth, Lynne. 1999. Audio-visual cataloging: From orphan child to Cinderella. Technicalities 19, no. 2 (Feb.): 1, 3-5.

$\mathrm{Hu}$, Jiajian. 1999. Chinese romanization in Library of Congress cataloging. Illinois Libraries 81, no. 4 (fall): 250-51.

Intner, Sheila. 1999. Back to the future of AV. Technicalities 19, no. 2 (Feb.): 6-9.

Irwin, Barbara. 1999. A fundamental of cataloguing efficiency: The automated batch method. Feliciter 45, no. 1: 14-15.

ISBD (CF) Review Group. 1997. ISBD (ER): International Standard Bibliographic Description for electronic resources; Revised from the ISBD $(\mathrm{CF})$ International Standard Bibliographic Description for Computer Files. Munchen: K. G. Saur.

Jantz, Ronald C. 1999. An approach to managing vocabulary for databases on the Web. Cataloging \& Classification Quarterly 28, no. 3: 55-66.

Joint Steering Committee for Revision of Anglo-American Cataloguing Rules. 1999. Outcomes of meeting held in Brisbane, Australia, October 18-20, 1999. Accessed May 3, 2000, www.nlc-bnc.ca/jsc/brisbane.htm.

Kandoian, Nancy A. 1999. Cataloging early printed maps. Cataloging \& Classification Quarterly 27, no. 3-4: 229-64.

Kgosiemang, Rose Tiny. 1999. Retrospective conversion: The experience at the University of Botswana Library. Cataloging \& Classification Quarterly 28, no. 3: 67-94.

Kniffel, Leonard. 1999. Cataloger demands reprimand be rescinded. American Libraries 30, no. 4 (Apr.): 20-22.

Konovalov, Yuri. 1999. Cataloging as a customer service: Applying knowledge to technology tools. Information Outlook 3, no. 9 (Sept.): 25-27.

Kuhn, Tamara J. 1999. Classifying newspapers using Dewey Decimal Classification. Library Resources \& Technical Services 43: 106-13.

Kulczak, Deborah E. 1999. Name authority work for OCLC copy cataloging: Is it worth the effort? Cataloging \& Classification Quarterly 28, no. 1: 69-81.

Kwansnik, Barbara H. 1999. The role of classification in knowledge representation and discovery. Library Trends 48, no. 4: 22-47.
Lahary, Dominique. 1999. UNIMARC as a cataloguing format in France. International Cataloguing and Bibliographic Control 28, no. 2: 50-52.

Landland, Kristen, ed. 1999. Ongoing entities: The impact of modified model C on cataloging description. Serials Review 25, no. 1: 95-108.

Lange, Holley R. 1999. Cataloging maps: Getting started. Colorado Libraries 25, no. 1: 40-41.

Larsgaard, Mary Lynette. 1999. Cataloging cartographic materials on CD-ROMs. Cataloging \& Classification Quarterly 27, no. 3-4: 363-74.

Leazer, Gregory H., and Richard P. Smiraglia. 1999. Bibliographic families in the library catalog: A qualitative analysis and grounded theory. Library Resources \& Technical Services 43: 191-212.

Lichtenbergova, Edita, and Bohdana Stoklasova. 1999. UNIMARC in Czech libraries. International Cataloguing and Bibliographic Control 28, no. 2 (Apr--June): 52-54.

Liu, Jessica. 1999. Review and prospect for centralized cataloging in China. Cataloging \& Classification Quarterly 28, no. 2: 57-64.

Lubetzky, Seymour. 1999. On the use of form headings in an alphabetical catalog. Library Quarterly 69, no. 2: 222-36.

Lundgren, Jimmie, and Betsy Simpson. 1999. Looking through users' eyes: What do graduate students need to know about Internet resources via the library catalog? Journal of Internet Cataloging 1, no. 4: 31-44.

Luttman, Stephen F. 1999. Good enough for jazz, or, successful music cataloging for non-musicians. Colorado Libraries 25, no. 2: 48-49.

MacEwan, Andrew. 1999. Working with LCSH: The cost of cooperation and the achievement of access. International Cataloguing and Bibliographic Control 28, no. 4 (Oct.-Dec.): 94-97.

Madison, Olivia M. A. 1999. Standards in light of new technologies functional requirements for bibliographic records. International Cataloguing and Bibliographic Control 28, no. 1 (Jan./Mar.): 7-10.

Manning, Ralph W. 1999. The Anglo-American Cataloging Rules and their future. International Cataloguing and Bibliographic Control 28, no. 3 (July-Sept.): 68-71.

Marcus, Sara. 1999. How to catalog a human, or, these things must be done delicately. American Libraries 30, no. 1 (Jan.): 94-95.

Martin, Rebecca. 1999. Notes for special collections in the MARC format for holdings data: Subfield Z. Technicalities 19, no. 7 (Aug.): 1, 8.

Martínez-Arellano, Filiberto Felipe. 1999. Subject searching in online catalogs including Spanish and English material. Cataloging \& Classification Quarterly 28, no. 2: 45-46.

McDermott, Irene E. 1999. Running rings around the Web. Searcher 7, no. 4 (Apr.): 67-70.

McDonnell, Janice P., Wallace C. Koehler Jr., and Bonnie C. Carroll. 1999. Cataloging challenges in an area studies virtual library catalog (ASVLC): Results of a case study. Journal of Internet Cataloging 2, no. 2: 15-41.

McEathron, Scott. 1999. The cataloging of globes. Cataloging d Classification Quarterly 27, no. 1-2: 103-12.

McIlwaine, I. C., and N. J. Williamson. 1999. International trends in subject analysis research. Knowledge Organization 26, no. 1: 23-29. 
McKiernan, Gerry. 1999. Points of view: Conventional and "neoconventional" access and navigation in digital collections. Journal of Internet Cataloging 2, no. 1: 23-41.

Mead-Donaldson, Robert. 1999. Classify your media! Technicalities 19, no. 1 (Jan.): 3-4.

Medeiros, Norm. 1999. Making room for MARC in a Dublin Core world. Online 23, no. 6 (Nov./Dec.): 57-60.

Miller, Eric, Eric Childress, and Erik Jul. 1999. Making progress: The resource description framework. Journal of Internet Cataloging 1, no. 4: 53-58.

Milstead, Jessica, and Susan Feldman. 1999. Metadata: Cataloging by any other name. Online 23, no. 1 (Jan./Feb.): 25-31.

1999b. Metadata: Projects and standards. Online 23, no. 1 (Jan./Feb.): 32-40.

Molyneux, Robert. 1999. May you live in interesting times. Technicalities 19, no. 2 (Feb.): 1, 10-13.

Moore, Susan. 1999. Navigating the G schedule. Cataloging o Classification Quarterly 27, no. 3-4: 375-84.

Morris, Dilys E., and Gregory Wool. 1999. Cataloging: Librarianship's best bargain. Library Journal 142, no. 11 (July 15): 44-46.

Murtomaa, Eeva. 1999. The impact of the functional requirements for bibliographic records recommendations on the ISBD (ER). Cataloging \& Classification Quarterly 28, no. 1: 33-41.

- 1999b. The Net is revolutionizing cataloguing. International Cataloguing and Bibliographic Control 28, no. 4 (Oct.-Dec.): 97-99.

Nafito, Michael. 1999. The indexed Web: Engineering tools for cataloging, storing, and delivering Web-based documents. Information Outlook 3, no. 2 (Feb.): 18-22.

Parker, Velma. 1999. Cataloguing maps series and serials. Cataloging \& Classification Quarterly 27, no. 1-2: 65-101. - 1999b. MARC tags for cataloging cartographic materials. Cataloging \& Classification Quarterly 27, no. 1-2: 5-8.

Porter, G. Margaret, and Laura Bayard. 1999. Including Web sites in the online catalog: Implications for cataloging, collection development and access. The Journal of Academic Librarianship 25, no. 5: 390-94.

Prescott, Dorothy. 1999. Early maps with or in printed publications: Description and access. Cataloging \& Classification Quarterly 27, no. 3-4: 285-301.

Rahman, Salimah Abd, and Adibah Ahmad Rafae. 1999. Cataloging and treatment of materials written in Jawi: Experiences of Malaysia. International Cataloguing and Bibliographic Control 28, no. 3 (July-Sept.): 73-75.

Ralston, Rick, and Margaret A. Rioux. 1999. With feet planted firmly in mid-air: Staff training for automation system migration. Serials Librarian 36, no. 3-4: 407-13.

Randall, Barbara Nichols. 1999. Spelling errors in the database: Shadow or substance? Library Resources \& Technical Services 43: 161-69.

Reynolds, Regina Romano. 1999. Harmonizing bibliographic control of serials in the digital age. Cataloging \& Classification Quarterly 28, no. 1: 3-19.

Riedlmayer, András J. 1999. "Ghost cataloging” and other tales of degraded access. Art Documentation 18, no. 1: 29-34.

Riesthuis, G. J. A., and R. Storm. 1999. GOO: The Dutch national system for subject indexing. International Cataloguing and Bibliographic Control 28, no. 4 (Oct.-Dec.): 91-93.
Robertson, Michelle Martin. 1999. Customizing the organization of local planning documents. Technicalities 19, no. 7 (Aug.): 6-7.

Rockwell, Ken. 1999. Problem areas in descriptive cataloging of sheet maps. Cataloging \& Classification Quarterly 27, no. 1-2: 39-63.

Roe, Sandy. 1999. Online subject access. Journal of Internet Cataloging 2, no. 1: 69-78.

Rogers, Michael, and Norman Oder. 1999. Citing "deception," Berman resigns from Hennepin County. Library Journal 124, no. 9 (May 15): 14.

. 1999b. Hennepin County rebukes Berman. Library Journal 124, no. 6 (Apr. 1): 13-16.

Romero, Lisa, and Nancy Romero. 1999. Cataloging early atlases: A reference source. Cataloging \& Classification Quarterly 27, no. 3-4: 265-84.

Sandberg-Fox, Ann. 1999. Principal changes in the ISBD (ER). International Cataloguing and Bibliographic Control 28, no. 3 (July-Sept.): 67.

Šauperl, Alenka, and Jerry D. Saye. 1999. Pebbles of the mosaic of cataloging expertise: What do problems in expert systems for cataloging reveal about cataloging expertise? Library Resources \& Technical Services 43: 78-94.

Scheschy, Virginia. 1999. Outsourcing: A strategic partnership. Technical Services Quarterly 16, no. 3: 31-41.

Seymour, Chaim. 1999. Retrospective conversion at Bar-Ilan University. Technicalities 19, no. 7 (Aug.): 4-5.

Sherwood, Arlyn. 1999. Enhancing in OCLC's map format: A participant's view. Cataloging \& Classification Quarterly 27, no. 3-4: 429-41.

Sill, Laura A. 1999. Training for the new serialist. Library Resources \& Technical Services 43: 247-56.

Sitas, Anestis. 1999. Greek folk literature, poetry, folk songs, and the Library of Congress PA (supplement) schedule. Cataloging \& Classification Quarterly 28, no. 1: 53-68.

Smiraglia, Richard P., and Gregory H. Leazer. 1999. Derivative bibliographic relationships: The work relationship in a global bibliographic database. Journal of the American Society for Information Science 50, no. 6: 493-504.

Smits, Jan. 1999. Metadata: An introduction. Cataloging \& Classification Quarterly 27, no. 3-4: 303-19.

- 1999b. Spatial metadata: An international survey on clearinghouses and infrastructures. Cataloging \& Classification Quarterly 27, no. 3-4: 321-42.

Spillane, Jodi Lynn. 1999. Comparison of required introductory cataloging courses, 1986 to 1999. Library Resources \& Technical Services 43: 223-30.

St. Lifer, Evan. 1999. Gregory Leazer: The new face of cataloging. Library Journal 124, no. 8 (May 1): 42-44.

Stibbe, Hugo L. P. 1999. Cataloguing cartographic materials in archives. Cataloging \& Classification Quarterly 27, no. 3-4: 443-63.

Stibbe, Hugo L. P., et al. 1982. Cartographic materials: A manual of interpretation for AACR2. Chicago: ALA.

Studwell, William. 1999. Does the information explosion mean cataloging implosion? A re-exploration. Technicalities 19, no. 3 (Mar.): 13-14.

- 1999b. Universal subject environment: Aspirations for a multinational, multicultural, and multilingual subject access system. Technical Services Quarterly 16, no. 3: 21-29. 
Su, Julie Tao. 1999. Keeping serial bibliographical records up-todate in local online catalogs: A study on record change and database maintenance. Serials Librarian 35, no. 4: 17-28.

Summers, Ed. 1999. Chaos-show me the metadata! Against the Grain 11, no. 1: 79-82.

Sutton, Stuart A. 1999. Conceptual design and deployment of a metadata framework for educational resources on the Internet. Journal of the American Society for Information Science 50, no. 13: 1182-92.

Swan-Hill, Janet. 1999. You may already know the answer. Serials Librarian 36, no. 1-2: 225-45.

Taniguchi, Shoichi. 1999. An analysis of orientedness in cataloging rules. Journal of the American Society for Information Science 50, no. 5: 448-60.

Taylor, Arlene G. 1999. Where does AACR2 fall short for Internet resources? Journal of Internet Cataloging 2, no. 2: 43-52.

Thiry, Christopher J. J. 1999. Cataloging geologic sections. Cataloging \& Classification Quarterly 27, no. 1-2: 113-45.

Tsvetkova, Irina, and Vladimir Skvortsov. 1999. Adaptation of UNIMARC as Russian Exchange Format. International cataloguing and bibliographic control 28, no. 2 (Apr--June): 54-56.

Turner, Thomas P., and Lise Brackbill. 1998. Rising to the top: Evaluating the use of HTML META tags to improve the retrieval of World Wide Web documents through Internet search engines. Library Resources \& Technical Services 42: 258-71.

Valauskas, Edward J. 1999. Digital information and the Internet: The special case of electronic journals. International Cataloguing and Bibliographic Control 28, no. 1 (Jan.-Mar.): 14-17.

Veatch, James R. 1999. Insourcing the Web. American Libraries 30, no. 1 (Jan.): 64-67.

Verrill Smith, Rebecca. 1999. Dewey Decimal classification of folklore for children. Technicalities 19, no. 8 (Sept.): 4-6.

Wang, Daphne Hsu-Kuang. 1999. Collections without collective title. Journal of East Asian Libraries 117 (Feb.): 19-97.

Warner, Amy J. 1999. A reaction to the findings of A study of library users and their understanding of subject headings. Technicalities 19, no. 4 (Apr.): 4-5.

Weber, Mary Beth. 1999. Factors to be considered in the selection and cataloging of Internet resources. Library Hi Tech 17, no. 3: 298-303.

Weibel, Stuart. 1999. The state of the Dublin Core metadata initiative. Bulletin of the American Society for Information Science 25, no. 5 (June-July): 18-22.
Weihs, Jean. 1999. Cardinal rule change and the OPAC Technicalities 19, no. 4 (Apr.): 1, 11-13.

Weihs, Jean, ed. 1998. The principles and future of AACR: Proceedings of the International Conference of the Principles and Future of AACR. Toronto, Ontario, Canada, October 23-25, 1997. Ottawa: Canadian Library Association.

Weimer, Katherine H. 1999. Subject analysis for cartographic materials. Cataloging \& Classification Quarterly 27, no. 3-4: 385-404.

Weinberg, Bella Hass. 1999. Improved Internet access: Guidance from research on indexing and classification. Bulletin of the American Society for Information Science 25, no. 2 (Dec.-Jan.): 26-29.

Weintraub, Jennifer, and Janet McKinney. 1999. The development and use of a genre statement for electronic journals. Serials Librarian 36, no. 3-4: 429-39.

Welch, Grace D., and Frank Williams. 1999. Cataloguing digital materials. Cataloging \& Classification Quarterly 27, no. 3-4: 343-62.

Wendler, Robin. 1999. Branching out: Cataloging skills and functions in the digital age. Journal of Internet Cataloging 2, no. 1: 43-54.

Wiles-Young, Sharon, and Linda Novak. 1999. What happened to the serials cataloger: Copy cataloging of serials. Serials Librarian 36, no. 3-4: 401-5.

Witt, Maria. 1999. Cataloguing CD-ROMs using the ISBD (ER) rules-Examples of a French public library. Cataloging \& Classification Quarterly 28, no. 1: 21-31.

Womble, Kathryn. 1999. Retrospective conversion and cataloging of a major academic map collection: The University of Washington story. Cataloging \& Classification Quarterly 27, no. 3-4: 413-28.

Yee, Martha M. 1999. One catalog or no catalog? ALCTS Online Newsletter 10, no. 4 (July). Accessed Apr. 3, 2000, www.ala.org/alcts/alcts_news/v10n6/gateway_pap14.html. - 1999b. Guidelines for OPAC displays. ALCTS Online Newsletter 10, no. 6 (Dec.). Accessed Apr. 3, 2000, www.ala.org/alcts/alcts_news/v10n6/gateway_pap14.html.

Zeng, Marcia Lei. 1999. Metadata elements for object description and representation: A case report from a digitized historical fashion collection project. Journal of the American Society for Information Science 50, no. 13: 1193-208.

Zuidema, Karen Huwald. 1999. Reengineering technical services processes. Library Resources \& Technical Services 43: 37-52. 